\title{
Persepsi Wisatawan Nusantara Terhadap Penyelenggaraan Pesta Kesenian Bali Sebagai Daya Tarik Wisata
}

I Wayan Rolly Yohan Kayansaa,1, I Made Adikampanaa, 2

1rollyyohankayansa@gmail.com, 2adikampana@unud.ac.id

a Program Studi S1 Destinasi Pariwisata, Fakultas Pariwisata,Universitas Udayana, Jl. Dr. R. Goris, Denpasar, Bali 80232 Indonesia

\section{Abstract}

Chaiman of the PHRI (Indonesia Hotel and Restaurant Association)said that the Bali Arts festival is not a appropriate to serve as a tourist attraction. Based on this research aims to know the perception of tourist on the implementation of the Bali Arts Festival as a tourist attraction.

The method in this study using a type of qualitative and quantitative data sources, the primary data, secondary data. The data collection is done by means of literature study, interviews, questionnaries, observations. Sampling technique in this study using a quota sampling, determine the sample using the formula Slovinwith the number of domestic tourists 50 people. Analysis of the data used is descriptive qualitative data analysis.

The results showed that the Bali Arts Festival can be used as a tourist attraction, because the event can attract tourists to visit.Based on the questionnaire that has been distributed, the Bali Arts festival can be used as a tourist attraction for many tourists can find products by the people of Bali, both for the preservation of Balinese culture, and increase the economic income of local communities

Keywords: Perception, Travelers Domestic, Bali Arts Festival, Tourist Attractions

\section{PENDAHULUAN}

Pariwisata sebuah industri yang baru berkembang setelah perang dunia ke- II dan mengalami perkembangan yang sangat pesat hampir di seluruh negara di dunia pada tahun 1990-an. Munculnya pariwisata disuatu negara atau daerah tentunya akan membantu perekonomian masyarakat dari adanya pengembangan daya tarik wisata di daerah tersebut. Hal tersebut tentunya juga akan berdampak pada sektor-sektor lain yang ikut berkembang beriringan dengan perkembangan sektor pariwisata seperti sektor pertanian, peternakan, perkebunan, kerajinan rakyat, dan peningkatan kesempatan kerja. Pentingnya peranan pariwisata dalam pembangunan ekonomi di berbagai negara sudah tidak diragukan lagi. Banyak negara sejak beberapa tahun terakhir menggarap pariwisata dengan serius dan menjadikan pariwisata sebagai sektor unggulan di dalam perolehan devisa, penciptaan lapangan kerja, maupun pengentasan kemiskinan (Pitana, 2002).

Di negara Indonesia merupakan sektor penghasil devisa nomor satu di luar non migas. Bagi Indonesia, jejak pariwisata dapat ditelusuri kembali ke dasawarsa 1910-an, yang ditandai dengan dibentuknya VTV (Vereeneging Toeristen Verkeer) sebuah badan pariwisata Belanda di Batavia. Badan pemerintah ini sekaligus bertindak sebagai tour operator dan travel agent yang segera gencar mempromosikan Indonesia, khususnya Jawa dan Bali. Pada tahun 1926 berdiri pula di Jakarta sebuah cabang dari Lislind (Lissonne Lindeman) yang pada tahun 1928 berubah menjadi Nitour (Nederlandsche Indische Touriten Bureau) sebagai anak perusahaan pelayaran Belanda KPM(Koninklijk Paketvaart Maatschapij) . KPM secara rutin melayani pelayaran yang menghubungkan Batavia, Surabaya, Bali, dan Makasar dengan mengangkut wisatawan (Vickers, 1989).

Bali merupakan salah satu Provinsi di negara Indonesia yang perkembangan pariwisatanya sangat pesat. Hal tersebut membuat Pemerintah dan pelaku pariwisata memfasilitasi kebutuhan wisatawan seperti membuat bandara, memberikan aksesbilitas yang memadai, dan tentunya memberikan pelayanan yang terbaik bagi wisatawan nusantara maupun wisatawan mancanegara. Umumnya wisatawan datang ke Bali menikmati keindahan alam dan seni budaya masyarakat Bali, mayoritas masyarakat Bali ber Agama Hindu. Daya tarik wisata di Bali bukan hanya menyajikan keindahan pemandangan alam yang eksotik, namun juga merupakan pusat kebudayaan tradisional Indonesia. Masyarakat melestarikan budaya dengan cara membuat event budaya Bali agar tetap lestari dan wisatawan bisa menikmati kunjungan wisatawanya, serta mensejahterakan masyarakat lokal sekitar daya tarik wisata. 
Bali yang terdiri dari 8 Kabupaten dan 1 Kotamadya memiliki daya tarik wisata unggulannya masing-masing. Kabuaten Badung yang terkenal dengan Pantai Seminyak, Kabupaten Gianyar yang terkenal dengan hamparan sawahnya di Tegalalang, Kabupaten Bangli yang terkenal dengan Trunyan, Kabupaten Klungkung yang terkenal dengan wisata spiritualnya seperti Pura Goa Giri Putri, Kabupaten Karangasem yang terkenal dengan daya tarik wisata Pantai Amed, Kabupaten Tabanan yang terkenal dengan daya tarik wisata Jatiluwih, Kabupaten Jembrana yang terkenal dengan Taman Nasional Bali Barat, Kabupaten Buleleng yang terkenal dengan Pantai Lovina, serta Kota Denpasar yang dikenal oleh wisatawan dengan budaya yang menjadi icon utama Kota Denpasar.

Salah satu daya tarik wisata yang ada di Kota Denpasar adalah Taman Budaya atau yang lebih dikenal dengan nama Art Centre. Art Centre ditetapkan sebagai daya tarik wisata dengan Keputusan Walikotamadya Tingkat II Denpasar Nomor 557 Tahun 1979 Tentang Penetapan Obyek dan Daya Tarik Wisata Kota Denpasar. Ditengah daya tarik wisata tersebut terdapat komplek bangunan dengan gaya arsitektur seni budaya tradisional Bali yang dibentuk pada tahun 1969 atas ide dari Gubernur Bali yaitu Alm. Prof. Dr. Ida Bagus Mantra. Art Centre sebagai wadah untuk menampung hasil karya seni masyarakat Bali tentunya para seniman tidak kesulitan untuk memasarkan atau memamerkan hasil karyanya yang akan ditujukan kepada masyarakat Bali dan dunia pada umumnya. Serta wisatawan yang berkunjung ke Art Centre akan mengetahui banyak hal tentang produk seni yang dihasilkan oleh masyarakat Bali.

Salah satu event tahunan yang terselenggara di Art Centre adalah Pesta Kesenian Bali. Event Pesta Kesenian Bali digagas pula oleh Alm. Prof. Dr. Ida Bagus Mantra pada tahun 1979 yang bertujuan untuk menampung hasil karya cipta seniman dan budayawan di seluruh penjuru Bali serta menangkal adanya akulturasi budaya. Penggalian dan pengembangan gagasan baru berkesenian dilakukan untuk menyeimbangi adanya distribusi budaya asing sebagai akibat adanya globalisasi menyeluruh. Seniman dari seluruh Bali menampilkan pertunjukan budaya dan seni, serta produk-produk seni lainnya seperti kerajinan tangan yang menarik minat wisatawan untuk membelinya. Berbagai pertunjukan seni bisa wisatawan saksikan setiap terselenggaranya Pesta Kesenian Bali,mulai dari seni wayang, sendratari, seni tari, kreasi baru, lukisan, patung, dan masih banyak produk yang ditawarkan saat terselenggaranya event tersebut.

Ada wacana yang menyebutkan bahwa Pesta Kesenian Bali tidak tepat untuk ditujukan pada kepentingan pariwisata. Ketua Perhimpunan Hotel dan Restoran Indonesia (PHRI) Tjokorda Oka Artha Ardana Sukawati atau yang akrab disebut Cok Ace menyatakan bahwa Pesta Kesenian Bali tidak tepat jika ditujukan untuk kepentingan pariwisata. Cok Ace menyatakan kalau Pesta Kesenian Bali sebagai daya tarik wisata, jadwal penyelenggaraan Pesta Kesenian Bali setiap tahunnya bisa berubah-ubah dan tidak bisa dimasukan dalam kalender pariwisata. Ketua Badan Promosi Pariwisata Daerah (BPPD) Bali mengingatkan kepastian waktu pertunjukan menjadi sangat penting sehingga pihaknya juga bisa bersinergi dengan kalangan Himpunan Pramuwisata Indonesia (Tribun News, Kamis 25 April 2015). Berdasarkan latar belakang tersebut penelitian ini bertujuan untuk mengetahui persepsi wisatawan nusantara terhadap penyelenggaraan Pesta Kesenian Bali sebagai daya tarik wisata.

\section{TINJAUAN PUSTAKA}

Telaah penelitian sebelumnya mengenai lokus dan fokus penelitian adalah sebagai berikut. Jurnal dari Mahardika 2015 dengan judul Festival Heritage Omed-Omedan Sebagai Daya Tarik Wisata di Sesetan, Denpasar. Penelitian Skripsi dari Wiyastini 2007 dengan judul Kegiatan Pesta Kesenian Bali XXVIII Sebagai Atraksi Wisata. Perbedaan antara kedua penelitian tersebut adalah disimpulkan Mahardika bahwa Sesetan Heritage OmedOmedan Festival dapat dijadikan daya tarik wisata, baik untuk turis nusantara maupun mancanegara. Hal tersebut dapat dilihat dari keunikan tradisi yang bentuk fisiknya tidak ditemukan di daerah lainnya maupun di Bali, Indonesia bahkan dunia, sedangkan Wiyastini lebih fokus terhadap potensi yang dimiliki Pesta Kesenian Bali sebagai atraksi wisata dan menekankan kesan stakeholders terhadap kegiatan Pesta Kesenian Bali. 
Adapun konsep dan teori yang digunakan dalam penelitian ini antara lain teori persepsi yang dikemukakan oleh (Walgito, 1990) yang mengatakan bahwa persepsi seseorang merupakan proses aktif yang memegang peranan, bukan hanya stimulus oleh individu melalui alat reseptornya, selanjutnya terjadi proses psikologis sehingga individu dapat menyadari apa yang di lihat dan di dengar. Teori wisatawan menurut (Suwantoro, 2004) wisatawan adalah seseorang atau kelompok orang yang melakukan suatu perjalanan wisata. Konsep Pesta Kesenian Bali berdasarkan website resmi Dinas Kebudayaan Provinsi Bali, mengatakan bahwa Pesta Kesenian Bali merupakan media dan sarana untuk menggali dan melestarikan seni budaya serta meningkatkan kesejahteraan. Serta teori daya tarik wisata menurut Undang-Undang Kepariwisataan Republik Indonesia Nomor 10 Tahun 2009 pasal I disebutkan bahwa daya tarik wisata adalah segala sesuatu yang memiliki keunikan, keindahan, dan nilai yang berupa keanekaragaman kekayaan alam, budaya, dan hasil buatan manusia yang menjadi sasaran atau tujuan kunjungan wisatawan.

\section{METODE PENELITIAN}

Lokasi Art Centre tepatnya di Jalan Nusa Indah, Denpasar Timur, kurang lebih 18 kilometer dari Bandara Ngurah Rai. Ruang lingkup dalam penelitian ini adalah event Pesta Kesenian Bali yang dikunjungi wisatawan nusantara tentunya memiliki pandangan tentang Pesta Kesenian Bali, yang dapat dijadikan sebagai daya tarik wisata. Jenis data dan sumber data yang digunakan yaitu data kualitatif dan data kuantitatif, serta data primer dan data sekunder. Teknik pengumpulan data dilakukan dengan cara studi kepustakaan, wawancara, kuesioner, observasi, instrumen penelitian ini berupa pedoman wawancara dan kuesioner. Teknik penentuan informan pada penelitian ini menggunakan quota sampling. Penentuan informan dimulai dengan menentukan informan pangkal yaitu mencari informasi di Dinas Kebudayaan Provinsi Bali dan di Art Centre, menentukan sample dengan menggunakan rumus Slovin dengan jumlah sample 50 orang wisatawan nusantara. Teknik analisis data yang digunakan adalah analisis data deskriptif kualitatif.

\section{HASIL DAN PEMBAHASAN}

\subsection{Hasil}

Art Centre merupakan sebuah komplek bangunan dengan gaya arsitektur seni budaya tradisional Bali dengan luas kurang lebih 14 hektar yang didalamnya terdapat beberapa gedung yang mendukung kegiatan Pesta Kesenian Bali. Pesta Kesenian Bali diadakan pertamakali pada tahun 1979 yang berlangsung kurang lebih dua bulan, yang pada setiap tahunnya memberikan kesempatan untuk menampilkan karya-karya seni terbaik sebagai wahana pembinaan, pelestarian, dan pengembangan seni budaya masyarakat Bali. Pihak yang terkait dalam penyelenggaraan Pesta Kesenian Bali melibatkan instansiinstansi seperti kepanitian dari Kabupaten Kota, Kabupaten Kota merupakan penyangga utama dari kegiatan penyelenggaraan Pesta Kesenian Bali. Sedangkan di Provinsi pihak penyelenggara Pesta Kesenian Bali melibatkan instansi dari kepemerintahan maupun swasta baik seniman maupun budayawan. Masyarakat lokal diberikan ruang dengan mengambil alih parkir disepanjang jalan Nusa Indah. Mengoordinasikan, mengkomunikasikan terhadap masyarakat di sekitar Art Centre dengan kelian-kelian banjar dan mengatur kondisi perparkiran di seputaran wilayah $\mathrm{Art}$ Centre sehingga terciptanya suasana yang aman dan nyaman.

Pengelolaan Pesta Kesenian Bali dari segi manajemen perlu mensiasati banyak hal dengan baik, dikarenakan penyelenggaraan Pesta Kesenian Bali adalah kegiatan yang berskala besar. Dengan itu pihak penyelenggara menyatukan banyak manajemen agar terciptanya penyelenggaraan yang tidak kalah bagusnya dari tahun lalu dan mengkoordinasikan organisasi-organisasi kesenian yang ada di seluruh Bali. Prioritas produk yang ditawarkan saat Pesta Kesenian Bali berlangsung adalah kerajinan-kerajinan yang mengacu pada produk budaya asli Bali seperti lukisan, kerajinan ukir, perak, tari, dan kerawitan.

Pesta Kesenian Bali merupakan event kegiatan masyarakat Bali yang memberikan ruang dalam rangka penggalian, pelestarian, dan pengembangan seni budaya Bali. Pesta Kesenian Bali merupakan proses pembinaan yang berkelanjutan serta membangun potensi budaya lokal, beralkulturasi dengan budaya 
nusantara dan mancanegara untuk mewujudkan keagungan peradaban dunia. Oleh karena itu pelaksanaan Pesta Kesenian Bali dihadapkan pada beragam peluang dan tantangan baik dalam tataran lokal, nasional, maupun global. Penyelenggaraan Pesta Kesenian Bali selama ini menampung hasil karya cipta seni dan aspirasi berkesenian. Penyelenggaraan tersebut merupakan upaya pemerintah dengan dukungan masyarakat untuk mensukseskan Bali sebagai Pulau pariwisata yang paling menarik di Indonesia. Event ini di ikuti oleh berbagai macam komponen masyarakat yang ada di Bali, dalam rangka mensukseskan program pariwisata di Pulau Bali. Namun bukan orang Bali saja yang ikut memeriahkan Pesta Kesenian Bali, orang dari luar daerah sampai luar negeri pun ikut serta. Peserta dari acara ini adalah instansi pemerintah, sekolah, sanggar, kelurahan, komunitas serta organisasi sosial. Masingmasing peserta menunjukan kebolehannya dengan berbagai atribut-atribut yang dibawakannya, disertai dengan atraksi tertentu untuk menarik perhatian penonton, khususnya para wisatawan dari dalam negeri maupun wisatawan luar negeri.

Penyelenggaraan Pesta Kesenian Bali tetap berjalan sesuai dengan amanat Perda No:4 Tahun 2006. Dengan Perda tersebut merupakan format atau bingkai yang harus dilaksanakan dimana dalam format Perda Pesta Kesenian Bali tersebut terdapat 5 materi pokok yang wajib dilaksanakan, yakni pawai, pagelaran, lomba dan parade, sarasehan, dan pameran. Pesta Kesenian Bali diselenggarakan sebagai upaya persembahan karya cipta seni terbaik masyarakat. Masyarakat yang berpartisipasi pada Pesta Kesenian Bali menunjukan, menampilkan, yang terbaik dan disertai dengan semangat persembahan. Kegiatan berkesenian tersebut didasari oleh motivasi sebagai persembahan yang terbaik dan spirit dalam segala aktivitas masyarakat Bali, melalui Pesta Kesenian Bali para seniman Bali diharapkan dapat terus berkarya dan berkreasi dalam upaya dan pengembangan kebudayaan Bali yang adiluhur, sekaligus pembangunan dari pariwisata daerah dan pembangunan masyarakat Bali.

Pesta Kesenian Bali belum layak dikatakan sebagai daya tarik wisata namun tidak sepenuhnya benar. Hal ini dibuktikan dengan persepsi wisatawan nusantara terhadap penyelenggaraan Pesta Kesenian Bali mendukung event tersebut sebagai daya tarik wisata. Berdasarkan hasil kuesioner yang disebarkan mengenai Pesta Kesenian Bali sebagai daya tarik wisata direspon sangat baik oleh wisatawan nusantara. Dengan alasan wisatawan yang berkunjung ke Pesta Kesenian Bali akan mengetahui bahwa Bali sebenarnya memiliki keanekaragaman budaya yang tidak terdapat diwilayah lainnya, lalu wisatawan bisa menyaksikan kembali kesenian-kesenian Bali yang hampir punah dan ajang penyelenggaraan Pesta Kesenian Bali baik untuk pelestarian budaya Bali. Berdasarkan konsep tentang daya tarik wisata, Pesta Kesenian Bali memiliki keunikan dan keanekaragaman budaya. Dilihat dari tarian, pagelaran, dan produk yang ditawarkan saat terselenggaranya kegiatan Pesta Kesenian Bali. Pesta Kesenian Bali dikatakan sebagai daya tarik wisata dikuatkan dengan penyelenggaraan tersebut mampu menarik minat wisatawan untuk berkunjung ke Art Centre melihat kegiatan Pesta Kesenian Bali. Penyelenggaraan Pesta Kesenian Bali memberikan wawasan bagi wisatawan nusantara khususnya wawasan tentang budaya asli Bali. Produk yang ditawarkan saat kegiatan Pesta Kesenian Bali berlangsung beranekaragam, dan para wisatawan nusantara dapat mengetahui bahwa pemerintah, masyarakat lokal, seniman dan budayawan telah memberikan yang terbaik bagi wisatawan saat menyaksikan pagelaran dan produk asli dari masyarakat Bali. Art Centre memadai sebagai tempat penyelenggaraan Pesta Kesenian Bali dikarenakan Art Centre memiliki tempat yang cukup luas sebagai tempat penyelenggaraan dan gedung-gedung yang terdapat di Art Centre dapat digunakan sebagai panggung yang sesuai dengan kegunaannya. Banyak hal menarik yang wisatawan dapatkan jika mengunjungi Art Centre saat terselenggaranya kegiatan Pesta Kesenian Bali, wisatawan akan banyak mengetahui tentang perjalanan sejarah, nilai sebuah seni tradisional masyarakat Bali maupun seni tradisional masyarakat Indonesia lainnya.

\subsection{Pembahasan}

$\begin{array}{rrrr}\text { 4.2.1 } & \begin{array}{l}\text { Persepsi wisatawan nusantara } \\ \text { terhadap }\end{array} & \text { penyelenggaraan Pesta }\end{array}$ 


\section{Kesenian Bali sebagai daya tarik wisata}

Untuk mengetahui persepsi wisatawan nusantara terhadap penyelenggaraan Pesta Kesenian Bali, maka kepada wisatawan nusantara yang berkunjung selama Pesta Kesenian Bali berlangsung diberikan daftar pertanyaan atau kuesioner dapat dilihat pada tabel-tabel berikut :

\section{Tabel 4.1}

Kegiatan yang menarik wisatawan nusantara berkunjung dalam kegiatan Pesta Kegiatan Bali.

\begin{tabular}{|c|c|c|c|}
\hline No. & Persepsi & $\begin{array}{c}\text { Jumlah } \\
\text { Wisatawan }\end{array}$ & Presentase \\
\hline 1. & Joged & 4 & $8 \%$ \\
\hline 2. & Kuliner & 14 & $28 \%$ \\
\hline 3. & $\begin{array}{c}\text { Pengrajin } \\
\text { Perak }\end{array}$ & 10 & $20 \%$ \\
\hline 4. & Lukisan & 22 & $44 \%$ \\
\hline 5. & Lain-lain & - & - \\
\hline \multicolumn{2}{|c|}{ Jumlah } & 50 & $100 \%$ \\
\hline
\end{tabular}

Sumber : hasil kuseioner 2015.

Berdasarkan tabel 4.1 dapat dilihat bahwa kegiatan yang menarik minat wisatawan nusantara berkunjung adalah lukisan dengan jumlah persentase 44\%. Hal tersebut dikarenakan wisatawan ingin mengetahui lebih detail tentang lukisan masyarakat Bali khususnya lukisan Wayang Kamasan, lukisan tersebut memiliki keunikan yang menggambarkan kehidupan dewa-dewa yang dipercayai oleh masyarakat Bali. Wisatawan memilih kuliner dengan jumlah persentase 28\% dikarenakan hanya ingin mencicipi kuliner Bali, khususnya ayam, sapi, dan bebek bagi wisatawan nusantara yang beragama Islam dan dengan adanya kuliner khas Bali baik bagi pelestarian kuliner Bali. Wisatawan memilih pengrajin perak dengan jumlah persentase $20 \%$ dikarenakan corak cincin, mainan kalung yang dimiliki sangat khas, dan wisatawan memilih joged dengan persentase $8 \%$ dikarenakan tarian tradisional tersebut sangat unik dan mengundang tawa wisatawan.

Tabel 4.2

Persepsi wisatawan nusantara terhadap fasilitas yang perlu ditambahkan saat kegiatan Pesta Kesenian berlangsung.

\begin{tabular}{|c|c|c|c|}
\hline No. & Persepsi & $\begin{array}{c}\text { Jumlah } \\
\text { Wisatawan }\end{array}$ & Presentase \\
\hline 1. & Toilet & 24 & $48 \%$ \\
\hline 2. & Parkir & 12 & $24 \%$ \\
\hline 3. & $\begin{array}{c}\text { Buku } \\
\text { Acara }\end{array}$ & 14 & $28 \%$ \\
\hline
\end{tabular}

\begin{tabular}{|c|c|c|c|}
\hline 4. & $\begin{array}{c}\text { Tempat } \\
\text { Informasi }\end{array}$ & - & - \\
\hline 5. & Lain-lain & - & - \\
\hline \multicolumn{2}{|c|}{ Jumlah } & 50 & $100 \%$ \\
\hline
\end{tabular}

Sumber : hasil kuseioner 2015.

Berdasarkan tabel 4.2 dapat dilihat bahwa fasilitas yang perlu ditambahkan adalah toilet dengan persentase $48 \%$, hal tersebut dikarenakan banyak gedung-gedung yang kurangnya fasilitas toilet tersebut terutama di tempat bermain anak-anak. Buku acara dengan jumlah persentase $28 \%$ dikarenakan wisatawan ingin mengunjungi Art Centre dengan mengetahui acara yang diselenggarakan esok harinya, dengan lebihnya buku acara tersebut akan banyak mendatangkan wisatawan. Sedangkan wisatawan memilih parkir dengan persentase $24 \%$ dikarenakan tempat parkir yang disediakan pihak penyelenggara dan masyarakat lokal kurang memadai sehingga wisatawan memarkir kendaraannya jauh dari terselenggaranya event tersebut.

Tabel 4.3

Persepsi wisatawan nusantara terhadap penyelenggaraan Pesta Kesenian Bali selama ini.

\begin{tabular}{|c|c|c|c|}
\hline No. & Persepsi & $\begin{array}{c}\text { Jumlah } \\
\text { Wisatawan }\end{array}$ & Presentase \\
\hline 1. & $\begin{array}{c}\text { Sangat } \\
\text { Baik }\end{array}$ & 37 & $78 \%$ \\
\hline 2. & Baik & - & - \\
\hline 3. & Cukup & 9 & $18 \%$ \\
\hline 4. & $\begin{array}{c}\text { Kurang } \\
\text { Baik }\end{array}$ & 4 & $8 \%$ \\
\hline 5. & $\begin{array}{c}\text { Sangat } \\
\text { Kurang } \\
\text { Baik }\end{array}$ & - & - \\
\hline \multicolumn{2}{|c|}{ Jumlah } & 50 & $100 \%$ \\
\hline
\end{tabular}

Sumber : hasil kuseioner 2015.

Berdasarkan tabel 4.3 dapat dilihat bahwa persepsi wisatawan nusantara terhadap penyelenggaraan Pesta Kesenian Bali selama ini direspon sangat baik oleh wisatawan dengan jumlah presentase 78\%, hal tersebut dikarenakan wisatawan mengetahui pihak penyelenggara sudah semaksimal mungkin untuk memberikan yang terbaik kepada wisatawan maupun masyarakat dan dilihat dari tema yang setiap tahunnya berbeda-beda. Wisatawan yang memilih cukup dengan jumlah presentase $18 \%$ dan kurang baik dengan jumlah presentase $8 \%$ dikarenakan wisatawan yang setiap tahunnya berkunjung ke ajang Pesta Kesenian Bali melihat kegiatan tersebut sama seperti tahun lalu, dan Pesta Kesenian Bali tahun ini agak sepi tidak seperti tahun- 
tahun sebelumnya, serta produk yang ditawarkan oleh para seniman dulunya murah sekarang menjadi sangat mahal.

Tabel 4.4

Persepsi wisatawan nusantara terhadap penyelenggaraan Pesta kesenian Bali sebagai daya tarik wisata.

\begin{tabular}{|c|c|c|c|}
\hline No. & Persepsi & $\begin{array}{c}\text { Jumlah } \\
\text { Wisatawan }\end{array}$ & Presentase \\
\hline 1. & $\begin{array}{c}\text { Sangat } \\
\text { Baik }\end{array}$ & 43 & $86 \%$ \\
\hline 2. & Baik & 7 & $14 \%$ \\
\hline 3. & Cukup & - & - \\
\hline 4. & $\begin{array}{c}\text { Kurang } \\
\text { Baik }\end{array}$ & - & - \\
\hline 5. & $\begin{array}{c}\text { Sangat } \\
\text { Kurang } \\
\text { Baik }\end{array}$ & - & - \\
\hline & Jumlah & 50 & $100 \%$ \\
\hline
\end{tabular}

Sumber : hasil kuseioner 2015.

Berdasarkan tabel 4.4 dapat diketahui bahwa persepsi wisatawan nusantara terhadap penyelenggaraan Pesta Kesenian Bali sebagai daya tarik wisata direspon sangat baik oleh wisatawan dengan jumlah presentase $86 \%$, hal tersebut dikarenakan wisatawan yang berkunjung akan mengetahui bahwa Bali sesungguhnya kaya akan budaya modern maupun budaya yang klasik, ajang Pesta Kesenian Bali yang setiap tahunnya rutin terselenggara sangat tepat dijadikan sebagai daya tarik wisata, dan baik untuk pelestarian budaya Bali. Sedangkan wisatawan yang memilih baik dengan jumlah presentase 14\% dikarenakan kegiatan Pesta Kesenian Bali mampu untuk menarik minat wisatawan untuk berkunjung melihat tarian maupun produk yang ditawarkan saat kegiatan tersebut berlangsung.

Tabel 4.5

Persepsi wisatawan nusantara terhadap produk yang ditawarkan saat kegiatan Pesta Kesenian Bali berlangsung.

\begin{tabular}{|c|c|c|c|}
\hline No. & Persepsi & $\begin{array}{c}\text { Jumlah } \\
\text { Wisatawan }\end{array}$ & Presentase \\
\hline 1. & $\begin{array}{c}\text { Sangat } \\
\text { Baik }\end{array}$ & 40 & $80 \%$ \\
\hline 2. & Baik & 10 & $20 \%$ \\
\hline 3. & Cukup & - & - \\
\hline 4. & $\begin{array}{c}\text { Kurang } \\
\text { Baik }\end{array}$ & - & - \\
\hline 5. & $\begin{array}{c}\text { Sangat } \\
\text { Kurang } \\
\text { Baik }\end{array}$ & - & - \\
\hline \multicolumn{2}{|c|}{ Jumlah } & 50 & $100 \%$ \\
\hline
\end{tabular}

Sumber : hasil kuseioner 2015.
Berdasarkan tabel 4.5 dapat diketahui bahwa persepsi wisatawan nusantara terhadap produk yang ditawarkan saat kegiatan Pesta Kesenian Bali berlangsung direspon sangat baik oleh wisatawan dengan jumlah presentase $80 \%$, hal tersebut dikarenakan lukisan seniman Bali sangat kental dengan keunikannya sehingga menarik minat wisatawan untuk membelinya. Wisatawan memilih baik dengan jumlah presentase $10 \%$ dikarenakan produk-produk yang ditawarkan oleh masyarakat Bali beranekaragam, sehingga wisatawan bisa mengetahui lebih dalam tentang produk yang dihasikan oleh masyarakat Bali.

\section{SIMPULAN DAN SARAN}

\subsection{Simpulan}

Melalui Pesta Kesenian Bali memotivasi masyarakat untuk menggali, menemukan, dan menampilkan kepada masyarakat. Kegiatan Pesta Kesenian Bali dapat di jadikan daya tarik wisata untuk wisatawan nusantara dan wisatawan mancanegara, hal ini di lihat dari keunikan produk yang ditawarkan saat terselenggaranya kegiatan Pesta Kesenian Bali. Kemauan masyarakat yang kuat didukung oleh kemampuan penyelenggara yang meningkat dari tahun ke tahun. Akses menuju ke Art Centre mudah dijangkau yang di lihat dari dekatnya lokasi Bandara Internasional Ngurah Rai.

Pesta Kesenian Bali dapat dijadikan sebagai daya tarik wisata dikuatkan dengan event tersebut dapat menambah pendapatan daerah, serta pendapatan masyarakat lokal, dan justru dengan Pesta Kesenian Bali dijadikan sebagai daya tarik wisata sangat tepat karena dapat melestarikan budaya Bali sekaligus menemukan kreasi baru berkesenian. Sesuai dengan konsep daya tarik wisata Pesta Kesenian Bali mampu menarik minat wisatawan untuk berkunjung ke Art Centre dalam terselenggaranya event tersebut.

Persepsi wisatawan nusantara terhadap penyelenggaraan Pesta Kesenian Bali sebagai daya tarik wisata direspon sangat baik oleh wisatawan yang berkunjung ke Art Centre saat terselenggaranya Pesta Kesenian Bali. Penyelenggaraan tersebut memiliki keunikan dan keanekaragaman budaya, yang di lihat dari tarian, pagelaran, dan produk yang ditawarkan saat penyelenggaraan tersebut berlangsung. Di lihat dari pertanyaan yang sudah diajukan rata- 
rata wisatawan nusantara menyimpulkannya dengan sangat baik, dikarenakan Pesta Kesenian Bali mampu menambah wawasan wisatawan tentang budaya Bali dan baik untuk keberlangsungan budaya Bali kedepannya.

\subsection{Saran}

Keberlangsungan kegiatan Pesta Kesenian Bali sebaiknya pihak panitia penyelenggara mengoreksi dalam memilih stand yang akan berjualan di Pesta Kesenian Bali. Hal tersebut bisa menjadi faktor wisatawan nusantara bosan berkunjung ke Pesta Kesenian Bali karena wisatawan saat menyaksikan kegiatan Pesta Kesenian Bali melihat hal yang sama dalam setiap tahunnya.

Dalam berlangsungnya setiap kegiatan ada baiknya menambahkan jadwal acara agar wisatawan bisa mengetahui bahwa keesokan harinya di Art Centre saat penyelenggaraan Pesta Kesenian Bali berlangsung ada kegiatan apa dan perlunya penambahan sarana toilet agar para wisatawan tidak bingung saat akan buang air. Ada baiknya jika masyarakat lokal terlibat dalam memeriahkan kegiatan penyelenggaraan Pesta Kesenian Bali dari segi keamanan agar masyarakat lokal tidak mendapatkan keuntungan dari lahan parkir, dan terciptanya kegiatan yang aman dan nyaman. Perlunya perhitungan secara kuantitatif dalam jumlah kunjungan wisatawan yang berkunjung saat kegiatan Pesta Kesenian Bali berlangsung, dikarenakan bisa mengetahui bahwa setiap tahunnya wisatawan yang berkunjung mengalami peningkatan atau mengalami penurunan.

\section{Daftar Pustaka:}

Anomin, 1979. Keputusan Walikotamadya Tingkat II Denpasar. Nomor 577. Tentang Penetapan Obyek dan Daya Tarik Kota Denpasar.

Anomin, 2009. Undang-undang Kepariwisataan Republik Indonesia. Nomor 10. Tentang Kepariwisataan.

Mahardika, Didik. 2015. Festival Heritage Omed-Omedan Sebagai Daya Tarik Wisata di Sesetan, Denpasar. Jumpa, Vol.1, No.2, Januari 2015.

Pitana, I Gde. 2002. Pariwisata, Wahana Kelestarian Kebudayaan dan Dinamika Masyarakat Bali. Denpasar Bali : Universitas Udayana.

Suwantoro, 2004. Dasar-dasar pariwisata. Yogyakarta : Andi Offset.

Tribun, News. Kamis, 2 April 2015.

Vickers, Andian. 1989. Bali : a Paradise Created. Hongkong : Periplus.

Walgito, Bimo. 1990. Pengantar Psikologi umum. Yogyakarta : Andi Offset.
Wiyastini, Desy. 2007. Kegiatan Pesta Kesenian Bali XXVIII Sebagai Atraksi Wisata. (Sebuah Laporan Akhir) Denpasar. Program Studi Pariwisata Universitas Udayana.

SUMBER LAINNYA :

(disbud.baliprov.go.id di unduh pada tanggal 12 Oktober 2016) 